Arhe XVII, 34/2020

UDK 321.01 Schmitt C.

321.06

DOI https://doi.org/10.19090/arhe.2020.34.295-309

Originalni naučni rad

Original Scientific Article

ORAZIO MARIA GNERRE ${ }^{1}$

Catholic University of the Sacred Heart of Milan, Italy

\title{
THE HISTORICAL ROLE OF SPAIN IN THE THOUGHT OF CARL SCHMITT
}

\begin{abstract}
Carl Schmitt's personal history was notoriously closely linked to Spain, a nation with which he also shared religious faith and therefore partly a culture of origin. But Schmitt's thought was linked to Spain for many other reasons, which made this country, for the German thinker, a very particular point of view on the destiny of the world. From the political predictions of Donoso Cortés, to the decline of Eurocentrism, to the elemental struggle between land and sea, to guerrilla warfare, the role of this Western European country remained preeminent for Schmitt in the history of civilization.
\end{abstract}

Keywords: Carl Schmitt, Spain, Donoso Cortés, Europe, Guerrilla warfare

The historic link that united the German thinker, theorist of law and political philosopher, Carl Schmitt, to Spanish civilization is widely known. This, in concrete terms, was frequently shown in the welcome that the Spanish academies gave him after the end of the Second World War, following which - as is well known - Schmitt suffered a process of relative ostracization, due to real or alleged connivance with the defeated political regimes, although he was nevertheless "saved" by the Nuremberg trial ${ }^{2}$. Although he, in the words he wrote to Armin Mohler, considered himself "a white crow who is not missing from any black list",

\footnotetext{
${ }^{1}$ Author's e-mail address: oraziognerre@ gmail.com

${ }^{2}$ Carl Schmitt, Ex Captivitate Salus, Adelphi, Milan 1987.
} 
this was partly valid both before ${ }^{3}$ and after the conflict, with the difference that - paradoxically - his intellectual fame and at the same time a certain diffidence towards him spread throughout Europe following 1945. Thus it was that the Plettenberg jurist found better hospitality in the Spanish academies, in a country that, having remained neutral during the war, had not seen any regime change. Without a doubt, this double attention, received by the Spanish world and subsequently reciprocated, is still tangible today in the writings of many Hispanic and Hispanic-speaking intellectuals.

Despite this, Schmitt's interest in Spain was not attributable to a mere opportunistic calculation, as some malicious literature would like, nor was it only existing at the beginning of the second half of the twentieth century. In fact, we can say that Spain, as a civilization, as a people and as a nation, already enjoyed a special position in the Schmittian system, as well as exercising an evident cultural fascination on him.

This is undoubtedly true, if one pays attention to the eminence that a classical figure of Spanish thought had for him. We are obviously talking about Donoso Cortés, the diplomat who the Spanish monarchy sent - in spite of himself in some ways - to Germany ${ }^{4}$, constituting a cultural bridge from which Schmittian thinking would benefit greatly, recovering it decades later 5 .

The figure of Cortés, central to the Catholic discourse of the beginning of the twentieth century, who had finally received his work and message globally, greatly influenced Carl Schmitt with regard to some

\footnotetext{
${ }^{3}$ The attacks on Schmitt by the National Socialist press are famous, especially as regards Das schwarze Korps, the German SS sheet, which defined him as a papist and a Roman.

Cfr. Andrea Mossa, Il nemico ritrovato. Carl Schmitt e gli Stati Uniti, Accademia University Press, Turin 2017.

${ }^{4}$ Cfr. Juan Donoso Cortés, Saggio sul Cattolicesimo, il liberalismo e il socialismo, Rusconi Editore, Milan 1972.

5 Carl Schmitt, Donoso Cortés interpretato in una prospettiva paneuropea, Adelphi, Milan 1996.
} 
fundamental structures of his thought ${ }^{6}$. The Spanish aristocrat, in fact, had seen a lot of attention on a whole series of political questions which, according to him, were badly posed in his contemporaneity ${ }^{7}$, and which in fact would explode in the near future ${ }^{8}$.

In any case, in addition to the fundamental questions of an eminently structural nature, Cortés's thought had proved, in Schmitt's eyes, often prophetic also under the aspect of world politics, relations between states and the destiny of the world, starting from famous statements on the socialist revolution in St. Petersburg rather than in London, and on the division of the earthly world between the rising American and Russian powers ${ }^{9}$. Indeed - Schmitt considered - Cortés's thought would return and would return knocking on the doors of humanity's attention every time a cycle of tragic or catastrophic events would reveal the great plots of divine designs, of the eternal anthropological ones or, as in this case, of the power games of lasting political entities ${ }^{10}$.

Therefore, the question of world politics could only be, for Schmitt who carefully considered political subjectivity not as an intrinsic or necessary expression of the national factor ${ }^{11}$, but rather of political will

\footnotetext{
${ }^{6}$ In this regard, I refer to the most widespread discussion in my work Prima che il mondo fosse. Alle radici del decisionismo novecentesco, Mimesis Edizioni, Milan 2018.

${ }^{7}$ Juan Donoso Cortés, Saggio sul Cattolicesimo, il liberalismo e il socialismo, Rusconi Editore, Milan 1972.

${ }^{8}$ Cfr. Carl Schmitt, Cattolicesimo romano e forma politica, Il Mulino, Bologna 2010.

9 Carl Schmitt, Donoso Cortés interpretato in una prospettiva paneuropea, Adelphi, Milan 1996.

${ }^{10}$ Ivi.

${ }^{11}$ It was this, among other things, that cost him the enmity of the National Socialists, who tended to share the Führer's fundamental idea expressed in Mein Kampf that the volk would necessarily produce its own systems of political organization in history. If this might seem true in relation to the Germans, a people defined with very broad morphological boundaries, it became much more problematic in relation to historically formed political entities that were evidently hybrid from an ethnic point of view, as for the Russians as he will write about them later. Lev Gümilev, as a fusion between Slavs and Tatars. This argument is actually true for most civilizations and historical empires,
} 
and organizing ideas, closely linked with historiography, which on the one hand it showed the complete relativity of national statehood ${ }^{12}$, on the other hand it described the close interrelation between "imperial" political entities and dominion over large territorial spaces ${ }^{13}$.

And if for Schmitt the particular, localized point of view we would say in his own words ${ }^{14}$, the starting point of his reasoning on the history of the world and on politics ${ }^{15}$, was Europe ${ }^{16}$, the Christianity of which Novalis wrote ${ }^{17}$, within this an area in which a particular type of civilization flourished, Spanish culture, the Kingdom of Spain and its Empire, played a particularly important role. In some moments, Spain even identified with Europe, and vice versa.

When we talk about Spain, we evidently find ourselves in the space of ambiguity in which it is poured into describing a national subject that pre-existed in its political autonomy the foundation of the modern state. If the monarchy of Spain, like that of France for example, had from a certain period onwards the awareness of dominating over a specific people, this however was also formed as a subject of the crown itself and as a participant in the historical deeds promoted by the royal family. The famous Argentine diplomat and scholar Abel Posse pointed out that, even in the thinking of the "most reactionary Hispanists", and all the more so

contradicting this Hitlerian extremization of some noble principles of nineteenthcentury romanticism, which demanded the merger of people and state in compliance with the natural right of self-determination.

${ }^{12}$ Ivi. Which Schmitt treats as a general idea formed in his overall theory by Bodin.

Cfr. Carl Schmitt, Il nomos della terra nel diritto internazionale dello «Jus publicum europaeum», Adelphi, Milan 1991.

${ }^{13}$ Carl Schmitt, Il nomos della terra nel diritto internazionale dello «Jus publicum europaeum», Adelphi, Milan 1991.

${ }^{14}$ On the concept of localization cfr. Carl Schmitt, Stato, grande spazio, nomos, Adelphi, Milan 2015.

${ }^{15}$ Besides, "the world is what happens" (Ludwig Wittgenstein, Tractatus logicophilosophicus, in Tractatus logico-philosophicus e Quaderni 1914-1916, Einaudi, Turin 2009).

${ }^{16}$ As in Carl Schmitt, Il nomos della terra nel diritto internazionale dello «Jus publicum europaeum», Adelphi, Milan 1991.

17 Novalis, La Cristianità ossia l'Europa, SE, Milan 2008. 
for the ruling family, the Indians of the Spanish colonies were always (or at least since the clergy asserted their reasons about the conquistadors ${ }^{18}$ ) considered as subjects of the kingdom ${ }^{19}$. This testifies to how the dimension of the kingdom and of the monarchy presupposed the extension of a culture rather than the domination of the ethnic identity of a people.

It is therefore clear that when Schmitt writes about Spain, the first interest, in line with the key concepts of his philosophy, is that of a political unity that becomes a people in history ${ }^{20}$.

We can read about the destinies of Spain in his works already from The concept of the "Political", where the role that the European country would have played in the destinies of history and modernity is taking shape for the first time with precision. According to Schmitt, it would have been the main brake, the katéchon we would say with another term dear to him ${ }^{21}$, to certain continental and world developments, which proceeded on certain structural vectors ${ }^{22}$.

\footnotetext{
${ }^{18}$ Regarding the role of the clergy, represented here in an emblematic figure, like Las Casas, Schmitt says: "It would nevertheless be a great distortion of Vitoria's thought to believe that he condemned the great Spanish conquest, considering it a wrong. This is certainly a very widespread error. In some older authors the misrepresentation is due to political hostility towards Spain; today it can only be attributed to superficiality". Carl Schmitt, Il nomos della terra nel diritto internazionale dello «Jus publicum europaeum», Adelphi, Milan 1991, p. 114 [translated from italian].

19 Abel Posse, Prologo, in Alberto Buela, L'Ispanoamerica contro l'Occidente, NovaEuropa Edizioni, Milan 2018.

${ }^{20}$ In open contrast to some ethnocentric theories of the State and of History which were often adopted, often for propaganda reasons, also by other European regimes besides the German one. On the other hand, this did not limit the positive function that the concept of people played in Schmitt's reasoning (cfr. Carl Schmitt, Stato, movimento, popolo, Si24, Palermo 2018), it simply inserted it into a harmonious discourse where it had to be reconciled with other elements. descriptive of the sphere of politics and society.

${ }^{21}$ Carl Schmitt, Terra e mare. Una riflessione sulla storia del mondo, Adelphi, Milan 2002.

22 Basically, the correspondence (volitional and non-deterministic) to certain geographical factors (to be understood in a technical sense, or better: of technical exploitation of the same) by some political entities. For example, England which
} 
It is no coincidence that, as a modern example par excellence of the famous dichotomy between friend and foe that he identified as the founding scheme of the politician, he used that between England and Spain in the $17^{\text {th }}$ century:

"For the modern era, I see the most violent outbreak of hostility of this kind $[\ldots]$ in Cromwell's struggle against papist Spain. In the speech of September 17, 1656 he says: "[...] The first thing I will say is what constitutes also the first lesson of nature: that is, to exist and to preserve oneself ... We must aim in the first place at that conservation of that "national existence peculiarly ours", in contrast to those who want to destroy it, and therefore make it not exist. Let us therefore consider our enemies [...] the enemies of the very existence of this nation" [...] and then continues: "Because, in fact, your great enemy is the Spaniard. He is a natural enemy. And it is naturally so, because of that enmity that is in him against all that is of God. All that is of God is in you, or could be in you". Then he reiterates: the Spaniard is your enemy, his [...] "enmity is placed in him by God", he is "[...] the natural enemy, the providential enemy", who considers him a "[... ] accidental enemy" does not know the Scriptures and the things of God, who said: "I will put enmity between your seed and his seed" (Genesis, III, 15); peace can be concluded with France, not with Spain, since it is a papist state, and the Pope keeps the peace only as long as he wants to". 23

In Carl Schmitt, the nature that the principle of enmity unveils with modernity and the end of Eurocentrism is well known. The total challenge that arises within Christianity, that religious struggle that flares up between Catholics and Protestants, and which only the Peace of Westphalia and the proclamation of the principle of interstate war can appease $^{24}$, will be rekindled later precisely with the embers still burning of the difference of worship. In the words of Cromwell reported by

decides to "become a fish" (cfr. Carl Schmitt, Terra e mare. Una riflessione sulla storia del mondo, Adelphi, Milan 2002).

${ }^{23}$ Carl Schmitt, Il concetto di "politico", in Le categorie del "politico", Il Mulino, Bologna 1988, p. 154 [translated from italian].

${ }^{24}$ Carl Schmitt, Il nomos della terra nel diritto internazionale dello «Jus publicum europaeum», Adelphi, Milan 1991. 
Schmitt, we can review the use of religious difference as the justifying foundation of total opposition: not a symmetrical relationship (as he says can exist with France), but one that is always unbalanced by the presence of the Pope, who according to the populace English represented the real and last political point of reference. Cromwell in fact used "antiCatholicism as a propaganda weapon in the fight against the Spaniards ${ }^{25}$.

The Peace of Westphalia, according to Carl Schmitt, had established a fundamental principle for the subsistence of Europe in the face of an external world, which the exploration and colonial expeditions had discovered: that of religious coexistence according to the famous motto di cuius regio, eius religio ${ }^{26}$. This exceptional concept, born as an attempt to settle the European split and overcome the internal stasis, of a religious war that increasingly assumed the contours of the civil war, however placed within the dialectical causes of its own end. If the European powers had the juridical obligation to respect themselves in their autonomous personality within the confines of Christianity, this constraint was less valid in the colonial sphere, where not only the limits towards indigenous peoples were set solely by the morality of their own religion of birth, but also the war formalities ${ }^{27}$ that existed between Christian countries disappeared.

The extra-Christian space saw the end of the intrachristian rules of challenge, and an effective race for territorial grabbing which, in fact, could also be easily justified with the same transcendent and salvific principles that had also been applied during the wars of religion.

Thus a phase of struggle began which put the champion of Catholicism, Spain, in contrast with the champion of anti-papism, England $^{28}$ : this struggle had the colonies as a battlefield. Despite the

${ }^{25}$ Gianpaolo Geravaglia, Società e religione in Inghilterra: $i$ cattolici durante la Rivoluzione, 1640-1660, Franco Angeli, Rome 1983, p. 119.

${ }^{26}$ Carl Schmitt, Il nomos della terra nel diritto internazionale dello «Jus publicum europaeum», Adelphi, Milan 1991.

${ }^{27}$ The concept of guerre en forme: Carl Schmitt, Il nomos della terra nel diritto internazionale dello «Jus publicum europaeum», Adelphi, Milan 1991, p. 438.

${ }^{28}$ Carl Schmitt, Il nomos della terra nel diritto internazionale dello «Jus publicum europaeum», Adelphi, Milan 1991. 
existence of other actors, first among them Portugal or France, the general challenge was between Catholic Spain and Anglican England, as well as strongly influenced by multiple Protestant beliefs.

"Spain and England have waged a bitter war with each other for a hundred years, in which the brutal hostility of which men may be mutually capable seems to have reached its highest degree. They have had no qualms about engaging non-Europeans, Mohammedans or Indians as overt or secret auxiliaries or even as allies. The outbursts of hostility are terrible: we mutually defined each other as murderers, thieves, rapists of women and pirates. ${ }^{, 29}$

All this, according to Schmitt, however, was part of a larger picture of events, which proceeded not only on the basis of the history of relations between powers, but also on the path of the evolution of the ways in which power was expressed. These modalities, according to Schmitt, were therefore not only linked to history, but also to geographical morphology, and constituted one with the life of human groups. This is how the complex concept of nomos in Schmittian thought was born.

If The Nomos of the Earth is Schmitt's text in which the decline of Eurocentrism is analysed in depth, that is, the recognition that Europe paid to itself as a single civilization founded on the common principles of law and Christianity, Land and Sea, a sort of supplementary essay to The Nomos of the Earth, conceived as a written story for his daughter Anima, instead focused on the movement from a certain type of organization of political spaces to another: from the nomos of the land, precisely, to the nomos of the $\mathrm{sea}^{30}$. In this great transition which outlines a general picture of the history of humanity, the historical role of Spain and of its double and opposite, England, was situated.

England, according to Schmitt, at a certain point in its existence had completely changed consciousness of its relations with the sea.

${ }^{29}$ Carl Schmitt, Terra e mare. Una riflessione sulla storia del mondo, Adelphi, Milan 2002 [translated from italian].

${ }^{30}$ Ivi. 
"England is an island. But only when it became the subject and centre of the elementary turn from the mainland to the high seas, only as heir to all the maritime energies then unleashed did it become the island that one thinks of when he repeats over and over that England is an island. And only after it became an island in a new and hitherto unknown sense did the British appropriation of the world's oceans and the first chapter of the planetary space revolution end. Of course England is an island. But with the observation of this geographical fact, not much is said yet. There are many islands whose political fates are very different." 31

It became aware of the role it could play in the world by completely reinterpreting the relationship with water, the same relationship that the Hegelian philosopher and geographer Ernst Kapp used in the nineteenth century to define the type of historical civilization of peoples ${ }^{32}$. It began a purely maritime existence, renouncing a simple organization of internal spaces, starting to think and put into practice the primarily economic possibilities (and necessarily not administrative, due to the physical nature of the waves) that the technique allowed in relation to the sea. And this it did first. What was to happen at that point, with respect to the most important spatial revolution ${ }^{33}$ that was looming before the eyes of the Spanish and English civilizations, that is, the discovery of the New World, was clearly delineated.

The wise use of the marine instrument, which in turn, as the philosophy of the twentieth century teaches, also modified the nature of the user, allowed England to improve the profitability of the colonies. After all, the New World has always been dominated from waters, as the historical lesson of gunboat diplomacy teaches ${ }^{34}$. So basically the phase of the maritime nomos was inaugurated, a phase in which a greater

\footnotetext{
${ }^{31}$ Ivi [translated from italian].

32 Ernst Kapp, Philosophische oder vergleichende allgemeine Erdkunde als wissenschaftliche Darstellung der Erdverhältnisse und des Menschenlebens, Braunschweig 1845.

${ }^{33}$ Carl Schmitt, Terra e mare. Una riflessione sulla storia del mondo, Adelphi, Milan 2002.

34 James Cable, Gunboat Diplomacy, 1919-1991, Palgrave MacMillan, London 1994.
} 
expansion of spatial horizons allowed those who had dominated the waters to win the enemy - in that phase, at least in the colonies.

Spain, on the other hand, was the representative of another type of relationship with space, the antecedent one, the nomos of the earth. Although engaged in the relentless extra-Christian struggle with England for the grabbing of the colonies, it nevertheless represented the rest of Christianity in the type of relationship with spaces.

This relationship, according to Schmitt, was the one determined by the telluric nomos. This was constituted by a certain type of bond that man developed with the environment and the space surrounding him, and which, until the "discovery" of the entirely maritime option by England, was proper to all peoples. Ernst Kapp spoke, in this regard, of potamic and thalactic stages of civilization ${ }^{35}$, categories still used in historiography, especially in the first case. The terrestrial way of life was characterized by a relationship of distribution and administration that one had towards the mainland, or at most territorial waters. Ultimately, it was also the spatial foundation of the juridical dimension of the jus publicum europaeum, the order born of the Peace of Westphalia, that is, the foundation of modern Europe ${ }^{36}$.

Spain imagined the world from the point of view of the land, and was still anchored to a vision based on the centrality of the European continent. England - or a part of it at least - was already slowly acquiring another consciousness, based on the equidistance of all territories from the sea:

"We speak referring to the sea of waterways although here there are only lines of communication and not roads as on land. We imagine a ship on the high seas as a piece of land traveling on the sea, as a floating piece of state territory as it is defined in the treatment of international law on this subject. A warship therefore seems to us a floating fortress and an island like England a fortress surrounded by

\footnotetext{
35 Ernst Kapp, Philosophische oder vergleichende allgemeine Erdkunde als wissenschaftliche Darstellung der Erdverhältnisse und des Menschenlebens, Braunschweig 1845.

${ }^{36}$ Carl Schmitt, Il nomos della terra nel diritto internazionale dello «Jus publicum europaeum», Adelphi, Milan 1991.
} 
the sea as by a wall. For the man of the sea, all of these are absolutely wrong metaphors arising from the imagination of land rats. A ship is not a floating piece of land, as little as a fish is a swimming dog. Conversely, for a purely maritime way of seeing, the mainland is simply a coast, a beach with a hinterland. Seen from the top of the sea and from a maritime existence, a whole country can even be just a simple wreck and waste of the sea. A surprising example for us, but typical of this way of seeing from the sea, is a statement by Edmund Burke who said: Spain is nothing more than a whale stranded on the coast of Europe."37

These visions of the elements, coexisting in reality but which in reality gave very important advantages or disadvantages in that particular phase of military appropriation and distribution, also spilled into the way of waging war between the two powers. If for Schmitt, for example, the Latins conceived the maritime battle as a particular form of the land battle, based on foot combat on the decks of ships ${ }^{38}$, so it is clear from his description of the war waged between the Spanish Empire and England a sort of persistence on the Spanish side in the model of guerre en forme, where the British were already making use of very new forms of conflict, thanks to the use of pirates, corsairs and other sea foam, to use the Schmittian term ${ }^{39}$.

"Whole categories of these daredevil pirates of the sea also achieved real historical fame as they gave the first blows to the Spanish world power and its commercial monopoly. Thus the Huguenot pirates in the fortress of La Rochelle who, at the time of Queen Elizabeth, fought against Spain allied with "the beggars of the sea", the Geusen. Then the so-called Elizabethan corsairs who made an essential contribution to the destruction of the Spanish Armada in 1588. The corsairs of Queen Elizabeth were followed by those of King James I and among these Sir Henry Mainwaring first one of the worst pirates, then pardoned in 1616 by the king and finally a hunter of pirates awarded with honours and offices. Then followed freebooters and savage

${ }^{37}$ Carl Schmitt, Terra e mare. Una riflessione sulla storia del mondo, Adelphi, Milan 2002 [translated from italian].

${ }^{38} \mathrm{Ivi}$.

${ }^{39} \mathrm{Ivi}$. 
buccaneers who made their important sorties moving from Jamaica and the Caribbean Sea: French, Dutch and English, including Sir Henry Morgan, who in 1671 sacked Panama and was then knighted by King Charles II and appointed Royal Governor of Jamaica. Their last heroic action was the conquest of the Spanish stronghold of Cartagena in Columbia which they conquered together with the French royal fleet in 1697 and plundered, after the French retreat, in a horrendous way." $" 40$

And thus, with the defeat of Spain by England in 1604 and the persistence of piracy against its colonies, the transformation of the world and the end of Eurocentrism took place. There was, as mentioned, a convergence between the end of the jus publicum europeaum and the transformation of the dominant nomos. In this convergence, England was both the vector and the object of the great change. Spain opposed it with a kind of frictional resistance, since the best grip on an element that became necessary, with the vision of an open space that would lead to the threshold of the oceanic civilization of which Kapp wrote ${ }^{41}$, guaranteed dominion.

However, Schmitt's treatment of Spanish history does not end with this transformation. A last act of this great drama ${ }^{42}$, as it will have to call it on Land and Sea, had to be represented: that of the birth of the guerrilla war.

The birth of the term "guerrilla" and its practice are, as is known, to be ascribed to the anti-Napoleonic resistance that Spain fought starting from 1808. In his essay on the figure of the partisan as a new image of world politics during the Cold War, Schmitt, after having dealt with the Vendée war, dwells precisely on the Spanish guerrilla ${ }^{43}$. If the tactics of the guerrilla war were thus born in the Vendée, with the resistance of the

\footnotetext{
40 Ivi [translated from Italian].

41 Ernst Kapp, Philosophische oder vergleichende allgemeine Erdkunde als wissenschaftliche Darstellung der Erdverhältnisse und des Menschenlebens, Braunschweig 1845.

${ }^{42}$ Carl Schmitt, Terra e mare. Una riflessione sulla storia del mondo, Adelphi, Milan 2002.

${ }^{43}$ Carl Schmitt, Teoria del partigiano. Integrazione al concetto del politico, Adelphi, Milan 2005.
} 
peasants to the French Revolution and to the political demands of the republican Paris, the figure of the partisan, however, is historically outlined in Spain. The Spanish partisan, fighting against the French forces, is basically the bearer of the flag of a party without a state, fighting an absolute battle (the concept of radical enmity returns) for victory or death.

If this figure will then evolve into the fighter of the irregular brigades during the Franco-Prussian War, the Second World War (with very wide advances on Spanish soil during the Civil War, towards which the International Brigades for example converged), the Cold War, it is with this last stage that, according to Schmitt, its essential value is finally made clear. It thus becomes clear how the partisan of the era in which the maritime nomos triumphs and the aerial one is looming ${ }^{44}$ is, for Carl Schmitt, the last fighter for the principle of the land ${ }^{45}$, with all that this means in Schmitt's thought. Taking his cue from the phenomena that he had before his eyes, as in the case of the Maoist guerrillas, or that had been told to him by the German officers who had fought in Italy, as in the case of the partisan brigades ${ }^{46}$, he realized how a greater divergence, in what will only then be called asymmetry, between the fighter who has the territory, and who once again embodies those principles of localization and bond with the soil which the German author has long dealt with, and those who by their nature do not he wants to administer (and therefore dominate in the proper sense) the terrain on which he fights. All this would then be amply demonstrated in the practice of the Afghan mujahideen, and in the difficulties that the Soviet and US armies have found themselves facing in conditions of asymmetry of this type. But, all in all, it was once again Spain that had anticipated the manifestations of the resistance of the telluric nomos.

\footnotetext{
${ }^{44}$ Of which he discusses in the correspondence with Ernst Jünger in the appendix to Land and Sea. Carl Schmitt, Terra e mare. Una riflessione sulla storia del mondo, Adelphi, Milan 2002.

${ }^{45}$ Carl Schmitt, Teoria del partigiano. Integrazione al concetto del politico, Adelphi, Milan 2005.

${ }^{46}$ Ivi.
} 
In a picture that for Schmitt must have been certainly bleak, with a Europe squeezed between two blocks of power and without any kind of autonomy, although he did not intend to propose any Eurocentric option but had an idea of a better distributed world power ${ }^{47}$ (in which, as he foresaw, the meek would inherit the earth ${ }^{48}$ ), in all probability the image of Spain, to be understood as a historical-existential entity that became a symbol of what it had made as a bulwark of a certain type of civilization, was a consolation.

\section{BIBLIOGRAPHY}

James Cable, Gunboat Diplomacy, 1919-1991, Palgrave MacMillan, London 1994.

Juan Donoso Cortés, Lezioni di diritto politico, Rubbettino, Soveria Mannelli 2008.

Juan Donoso Cortés, Saggio sul Cattolicesimo, il liberalismo e il socialismo, Rusconi Editore, Milan 1972.

Gianpaolo Geravaglia, Società e religione in Inghilterra: $i$ cattolici durante la Rivoluzione, 1640-1660, Franco Angeli, Rome 1983.

Orazio Maria Gnerre, Prima che il mondo fosse. Alle radici del decisionismo novecentesco, Mimesis Edizioni, Milan 2018.

Kenneth J. Hagan, American gunboat diplomacy and the old Navy, 1877-1889, Greenwood Press, Westport 1973.

José Rafael Hernandez Arias, Donoso Cortés und Carl Schmitt: eine Untersuchung über die staats- und rechtsphilosophische Bedeutung von Donoso Cortés im Werk Carl Schmitts, Verlag Ferdinand Schöningh, Paderborn 1998.

Ernst Kapp, Philosophische oder vergleichende allgemeine Erdkunde als wissenschaftliche Darstellung der Erdverhältnisse und des Menschenlebens, Braunschweig 1845.

James MacDermott, England and the Spanish Armada: The Necessary Quarrell, Yale University Press, London 2005.

${ }^{47}$ Carl Schmitt, Stato, grande spazio, nomos, Adelphi, Milan 2015.

48 Carl Schmitt, Ex Captivitate Salus, Adelphi, Milan 1987. The evangelical appeal to meekness was a counterbalance to the accumulation of destructive power by the blocks of the Cold War, an accumulation that presaged catastrophic outcomes for all mankind. 
Andrea Mossa, Il nemico ritrovato. Carl Schmitt e gli Stati Uniti, Accademia University Press, Turin 2017.

Novalis, La Cristianità ossia l'Europa, SE, Milan 2008.

Carl Schmitt, Cattolicesimo romano e forma politica, Il Mulino, Bologna 2010.

Carl Schmitt, Donoso Cortés interpretato in una prospettiva paneuropea, Adelphi, Milan 1996.

Carl Schmitt, Ex Captivitate Salus, Adelphi, Milan 1987.

Carl Schmitt, Il nomos della terra nel diritto internazionale dello «Jus publicum europaeum», Adelphi, Milan 1991.

Carl Schmitt, Le categorie del “politico”, Il Mulino, Bologna 1988.

Carl Schmitt, Stato, grande spazio, nomos, Adelphi, Milan 2015.

Carl Schmitt, Stato, movimento, popolo, Si24, Palermo 2018.

Carl Schmitt, Teoria del partigiano. Integrazione al concetto del politico, Adelphi, Milan 2005.

Carl Schmitt, Terra e mare. Una riflessione sulla storia del mondo, Adelphi, Milan 2002.

\section{ORACIO MARIJA NJERE}

Katolički univerzitet Svetog srca, Milano, Italija

\section{ISTORIJSKA ULOGA ŠPANIJE U MISLI KARLA ŠMITA}

Sažetak: Lična istorija Karla Šmita notorno je blisko povezana sa Španijom, nacijom s kojom je delio i religijsku veru, a stoga delimično i kulturu porekla. Ali Šmitova misao bila je vezana za Španiju i zbog niza drugih razloga, koji su tu zemlju učinili, za nemačkog mislioca, veoma specifičnom tačkom gledišta povodom sudbine sveta. Od političkih predviđanja Donosa Kortesa, propasti evrocentrizma, elementarne borbe između zemlje i mora, pa do gerilskog ratovanja, uloga ove zapadnoevropske države za Šmita je ostala najznačajnija u istoriji civilizacije.

Ključne reči: Karl Šmit, Španija, Donoso Kortes, Evropa, gerilsko ratovanje

Primljeno: 19.8 .2020 .

Prihvaćeno: 30.10 .2020 . 